\title{
Shoot Organogenesis in Callus Induced from Pedicel Explants of Common Bean (Phaseolus vulgaris $\mathbf{L .}$ )
}

\begin{abstract}
Mohamed F. Mohamed', Dermot P. Coyne ${ }^{2}$, and Paul E. Read ${ }^{3}$
Department of Horticulture, University of Nebraska, Lincoln, NE 68583-0724

Additional index words. benzyladenine, indoleacetic acid, pedicel, plant regeneration, somaclonal variation, thidiazuron, tissue culture

Abstract. Plant regeneration has been achieved in two common bean lines from pedicel-derived callus that was separated from the explant and maintained through successive subcultures. Callus was induced either on $B_{5}$ or MS medium containing $2 \%$ sucrose and enriched with 0.5 or $1.0 \mathrm{mg}$ thidiaznron/liter alone or plus various concentrations of indoleacetic acid. The presence of 0.07 or $0.14 \mathrm{~g}$ ascorbic acid/liter in the maintenance media prolonged the maintenance time. Up to 40 shoot primordia were observed in 4-week-old cultures obtained from 40 to $50 \mathrm{mg}$ callus tissues on shoot-induction medium containing 1-mg benzyladenine/liter. These shoot primordia developed two to five excisable shoots $(>0.5 \mathrm{~cm})$ on medium with $0.1-\mathrm{mg}$ BA/liter. A histological study confirmed the organogenic nature of regeneration from the callus tissues. The $R_{2}$ line from a selected variant plant showed stable expression of increased plant height and earlier maturity. Chemical names used: ascorbic acid, $N$ - (phenylmethyl)-1H-pnrin-6-amine [benzyladenine, BA], 1H-indole-3-acetic acid (IAA), $N$ - phenyl-N'-1,2,3-thiadiazol-5-ylurea [thidiazuron, TDZ].
\end{abstract}

Large-seeded legumes are difficult to regenerate from callus cultures. However, much progress has been made recently with soybean [Glycine $\max$ (L.) Merrill] (Barwale et al., 1986; Ghazi et al., 1986; Ranch et al., 1985) and with pea (Pisum sativum L.) (Kysely et al., 1987). Common bean, the most economically important Phaseolus species, has not been responsive to these procedures and is considered recalcitrant (Angelini and Allavena, 1989; Angelini et al., 1990). Kumar et al. (1988) regenerated plants from cell suspension Culture from leaf-derived callus in P. acutifolius A. Gray, and Angelini and Allavena (1989) regenerated plants from immature cotyledons of $P$. coccineus $\mathrm{L}$. Tissue culture studies with $P$. vulgaris have been confined primarily to meristem culture (Kartha et al., 1981), propagation via axillary shoot proliferation from shoot tips (Saam et al., 1987), shoot regeneration from excised leaf petioles (Malik and Saxena, 1991), cotyledonary explants (Mohamed et al., 1991) or embryonic axis cultures (Mohamed et al. 1992a), and direct shoot organogenesis on seedling nodes in the absence (McClean and Grafton, 1989; Mohamed et al., 1992b) or in the presence (Franklin et al., 1991) of axillary meristems.

There are no previous reports on shoot morphogenesis from callus tissues in common bean. This method of tissue culture for plant regeneration can lead to somaclonal changes (Evans and Bravo, 1986; Larkin and Scowcroft, 1981) that may give rise to useful genetic variants (Bajaj, 1990; Larkin and Scowcroft, 1981). The method can thus broaden the genetic variability available for plant breeders and offer new approaches to improve crop species via in vitro selection.

\footnotetext{
Received for publication 23 Mar. 1992. Accepted for publication 29 July 1992 Published as paper no. 9845, Journal Series, Nebraska Agricultural Research Division. Research was conducted under Title XII Bean/Cowpea CRSP Project, Univ. of Nebraska, Univ. of Puerto Rico, and Dominican Republic under AID contract no. DNA-1310-G-SS-6008-00 and also under Project no. 20-036. M.F.M. thanks Ellen Paparozzi and Liz Conley for their technical assistance in the histological study. The cost of publishing this paper was defrayed in part by the payment of page charges. Under postal regulations, this paper therefore must be hereby marked advertisement solely to indicate this fact.

${ }^{1}$ Visiting Scientist from Dept. of Horticulture, University of Assiut, Assiut, Egypt.

${ }^{2}$ George Holmes Regents Professor.

${ }^{3}$ Professor and Head.
}

The objective of this study was to explore and develop methods for consistent shoot morphogenesis and plant regeneration from callus cultures of common bean.

\section{Materials and Methods}

Four Great Northern (GN) beans ('Beryl', 'Harris', 'Starlight', and 'Tara') and one breeding line (Xan-159, CIAT) were used. Seeds from these lines were planted in $20-\mathrm{cm}$ clay pots containing 1.8 liters of soil mixture [1 soil : 1 sand : 5 sphagnum peat : 5 vermiculite (by volume) on 20 Mar. and 12 Sept. 1990 . The bean lines at both planting dates were arranged in randomized complete blocks and replicated four times. Plants were grown in the greenhouse under the existing photoperiods in Lincoln, Neb. $\left(40^{\circ} 51^{\prime} \mathrm{N}\right.$ lat.). The greenhouse was maintained at $\approx 25 / 20 \mathrm{C}$ (day/night). The growing plants were fertilized weekly with $200 \mathrm{ppm} \mathrm{N}$ supplied from a 6N-6.4P-13.6K fertilizer.

In vitro study. Hypocotyls, epicotyls, and cotyledonary leaves were excised from 7-day-old seedlings. Shoot tips $(1$ to $1.5 \mathrm{~cm})$ and unopened green flower buds ( 2 to $3 \mathrm{~mm}$ ) were collected 15 and 30 days after planting, respectively. Explants were surfacesterilized by soaking for 1 to $2 \mathrm{~min}$ in $70 \%$ ethanol, then for $10 \mathrm{~min}$ in $0.75 \% \mathrm{NaOCl}$ solution plus two to three drops Tween20 (Sigma, St. Louis) per $100 \mathrm{ml}$. Explants were rinsed three times with sterile deionized water. Hypocotyls and epicotyls were cut into 2- to 3-mm-long segments. Leaf explants were cut into $3 \mathrm{~mm}^{2}$ pieces. The flower buds (2 to $3 \mathrm{~mm}$ ) were removed and the remaining pedicel tissues were used for culture.

Explants from the various sources were placed into $100 \times$ $15 \mathrm{~mm}$ disposable petri dishes containing $25 \mathrm{ml}$ of nutrient medium solidified with $0.6 \%$ agar (Difco Labs, Detroit). The nutrient medium contained the salts and vitamins of either $\mathrm{B}_{5}$ (Gamborg et al., 1968) or MS (Murashige and Skoog, 1962). Each medium was used at two concentrations (w/v) of sucrose ( $2 \%$ and $4 \%)$ alone or with TDZ (0.5 and $1 \mathrm{mg} \cdot$ liter $\left.^{-1}\right)$. TDZ was supplemented from stock solution containing $0.2 \mathrm{mg}$ TDZ/ $\mathrm{ml}$ dissolved in $1 / 4 \mathrm{~N} \mathrm{KOH}$. The $\mathrm{pH}$ of these media was adjusted to 5.7 with $\mathrm{HCl}$ or $\mathrm{KOH}$ before autoclaving at $121 \mathrm{C}$ and 120 $\mathrm{kPa}$ for $20 \mathrm{~min}$. IAA was filter-sterilized and added to the autoclaved media at the following concentrations: $0,0.125,0.25$, or $0.5 \mathrm{mg} \cdot$ liter $^{-1}$ to media containing $0.5 \mathrm{mg}$ TDZ/liter; $0,0.25$, 
0.5 , or $1 \mathrm{mg} \cdot$ liter $^{-1}$ to media containing TDZ at $1 \mathrm{mg} \cdot \mathrm{liter}^{-1}$. Tissue cultures were initially incubated for a week at $25 \mathrm{C}$ in darkness and then placed for five additional weeks under coolwhite light $\left(25 \mu \mathrm{mol} \cdot \mathrm{m}^{-2} \cdot \mathrm{s}^{-1} 16 \mathrm{~h} \cdot \mathrm{day}^{-1}\right)$ from fluorescent lamps.

Percentages of explants forming proliferative viable callus and the color and texture of callus tissues were determined 6 weeks after culture of explants. Since proliferative and viable callus was obtained only from pedicel explants of GN 'Tara' and Xan- 159 on $\mathrm{B}_{5}$ and MS media containing $2 \%$ sucrose, callus was increased from these treatments only. Callus tissues were separated from the pedicel explants and subcultured (40 to 50 $\mathrm{mg}$ ) on fresh corresponding callus induction medium. Four weeks later, pieces (40 to $50 \mathrm{mg}$ ) from the proliferative callus tissues of the first passage (subculture) were selected at random to represent the various treatments of IAA/TDZ supplements within each nutrient medium (B, and MS) and bean line (GN 'Tara' and Xan-159) and then placed on maintenance medium or used in shoot induction experiments. Due to the higher weight of green viable callus in the first passage on media containing $\left(\mathrm{mg} \cdot\right.$ liter $\left.^{-1}\right) 0.25 \mathrm{IAA}+0.5 \mathrm{TDZ}$ for Xan-159 and 0.5 IAA +1 TDZ for GN 'Tara' than the other IAA/TDZ media (data not shown), these treatments were chosen for callus maintenance. Filter-sterilized ascorbic acid (adjusted to $\mathrm{pH}$ 5.7), which was beneficial for long-term tobacco callus maintenance as well as for young tissue lines (Joy-Iv et al., 1988), was added (0, 0.07 , and $0.14 \mathrm{~g} \cdot$ liter $\left.^{-1}\right)$ to the autoclaved callus maintenance media. Callus tissues for maintenance were serially subcultured once every 4 weeks to fresh medium of the same composition.

Callus pieces for shoot induction were placed on the corresponding type of nutrient medium $\left(\mathrm{B}_{5}\right.$ or $\left.\mathrm{MS}\right)$ containing $2 \%$ sucrose and supplemented with $1 \mathrm{mg}$ BA/liter or $0.05 \mathrm{mg}$ TDZ/ liter. Basal media without BA and TDZ supplements were used as controls. The experiments on shoot morphogenesis were conducted using the first and the fifth passage calli. Callus tissues of the fifth passage were from maintenance medium containing ascorbic acid, since callus tissues were maintained for only three to four subcultures on medium lacking ascorbic acid. Separate experiments were conducted for each bean line (GN 'Tara' and Xan-159) with the proliferating callus of the first and the fifth passages. The treatments in each experiment were arranged as split-plot in a randomized complete-block design with four replicates. The replication used throughout the various stages of in vitro study was the same as those used for seed planting in the greenhouse. Nutrient media $\mathrm{B}_{5}$ and MS represented the whole plots. The subplot treatments were the supplements BA and TDZ, in addition to the control. Each subplot experimental unit consisted of four baby food jars (two callus pieces per jar).

Tissues developing shoot primordia after 4 weeks on the shoot induction media were divided into pieces having three to four shoot primordia. Differentiated tissues from media without BA and TDZ were transferred to the same fresh basal mediun. Differentiated tissues from media containing BA or TDZ were transferred to fresh corresponding nutrient medium containing one-tenth the concentration of BA or TDZ used for induction of shoot morphogenesis (i.e., $0.1 \mathrm{mg}$ BA/liter or $0.005 \mathrm{mg}$ TDZ/liter). After 5 to 6 weeks, individual shoots $(>5 \mathrm{~mm})$ were separated and transferred to medium without BA or TDZ for rooting and elongation. Number of shoot primordia, elongated shoots $(>0.5 \mathrm{~cm})$, and plantlets produced from 40 to $50 \mathrm{mg}$ of callus tissues were determined.

The regenerated plantlets ( 3 to $4 \mathrm{~cm}$ ) were transplanted into small plastic pots containing $100 \mathrm{ml}$ of sphagnum peat and kept in a mist chamber for 7 to 12 days. Established plantlets were transferred to clay pots containing 1.8 liters of 1 soil : 1 sand : 5 sphagnum peat : 5 vermiculite (by volume) mixture and then moved to the greenhouse.

Histological study. Samples of callus tissues were collected after 6 weeks of culturing explants on callus induction media. Also, calli were sampled following each subculture on maintenance media. Callus cultures on regeneration media were removed at weekly intervals. All selected samples were immediately fixed in FAA: $100 \%$ ethanol/glacial acetic acid/40\% formalin $(10 / 1 / 2,+7$ parts of water, by volume). Following dehydration in an ethanol/Hemo-De series, the material was infiltrated and embedded in paraplast. Microtome sections were cut $15 \mu \mathrm{m}$ thick, mounted on glass slides, dewaxed in Hemo-De, and rehydrated in a descending ethanol series. Sections were stained with safranin 0 overnight $(\approx 15 \mathrm{~h})$ and then in fast green for 2 to $3 \mathrm{sec}$.

Variant plant evaluation. A total of 28 and 44 tissue culturederived plants $\left(\mathrm{R}_{0}\right)$ from GN 'Tara' and Xan-159, respectively, were grown in the greenhouse. All $\mathrm{R}_{0}$ plants were self-pollinated to produce $R_{1}$ seeds. Samples of seeds from the original explant source were grown at the same time and the plants were also selfed $\left(S_{1}\right) . R_{1}$ plants were observed for variability among progenies and within each progeny. Two variant plants based on plant height (centimeters) were selfed to produce $\mathrm{R}_{2}$ seeds. $\mathrm{S}_{2}$ seeds were also produced. The two $\mathrm{R}_{2}$ progenies along with $\mathrm{S}_{2}$ plants (control) were evaluated in a greenhouse experiment (started 18 Sept. 1991) using a randomized complete-block design with three replicates. Each replicate consisted of 20 seeds from each progeny. Data were collected for plant height (centimeters), days to flowering and maturity, flower color, and dry seed color and size (grams).

Statistical analysis. Separate and combined analyses of variance of the data from the two planting dates were performed using the general linear models (GLM) procedure of the SAS statistical package (SAS Institute, 1982). Least significant difference (LSD) values for various mean comparisons were calculated (Gomez and Gomez, 198.4).

\section{Results}

In vitro study. Hypocotyl, epicotyl, and leaf segments on $\mathrm{B}_{5}$ or MS medium with $2 \%$ or $4 \%$ sucrose but lacking TDZ and IAA/TDZ died 10 to 15 days after culture. Shoot tips placed on the same media developed single plantlets 3 to 4 weeks after culture, while pedicel explants formed only roots. In the presence of TDZ or IAA + TDZ, hypocotyl, epicotyl, and leaf explants expanded and increased rapidly in size during the first 2 weeks in culture but, 2 weeks later, tissues either died or developed little callus that turned brown and died. Cultures of shoot tips on media with TDZ and IAA + TDZ developed multiple shoots in the form of rosettes. Yellow, loose callus was also induced on the basal cut surface of the shoot tips. The callus tissues from shoot tip explants deteriorated and died within the 6 weeks of the primary culture period.

Eleven to $56 \%$ of pedicel explants from GN 'Tara' and Xan159 developed compact green nodular callus that proliferated and remained viable through successive subcultures. Callus was initiated from the terminal and basal regions of the pedicel 4 to 5 weeks after culture on $\mathrm{B}_{5}$ and MS media containing $2 \%$ sucrose and supplemented with 0.5 or $1.0 \mathrm{mg}$ TDZ/liter alone, or plus various levels of IAA. These callus tissues lost their ability to proliferate after the fourth passage when serially subcultured on maintenance medium without ascorbic acid. Addition of 0.07 
or $0.14 \mathrm{~g}$ ascorbic acid/liter prolonged the maintenance time to six passages. Calli induced from pedicel cultures with various supplements of IAA/TDZ on media containing $4 \%$ sucrose was very compact and became brown by the end of the primary culture period.

Callus pieces (40 to $50 \mathrm{mg}$ ) of GN 'Tara' and Xan-159 from first and fifth passage in culture increased $\approx 8$ to 15 times in size during the first 2 weeks after their transfer to shoot induction medium, then differentiated into dark-green, smooth, shiny meristem-like structures. Shoot primordia were visible 2 weeks later (Fig. 1). Once shoot primordia developed, callus proliferation ceased. The number of shoot primordia for the two bean lines was affected by the interaction between the type of nutrient medium and the supplements in the media, but no interaction effects for planting dates were detected in the combined analysis of variance. More shoot primordia differentiated from callus tissues of both bean lines on $\mathrm{B}_{5}$ medium than on MS medium at $1 \mathrm{mg} \mathrm{BA} / \mathrm{liter}$ (Table 1), but not at $0.05 \mathrm{mg}$ TDZ/liter (except

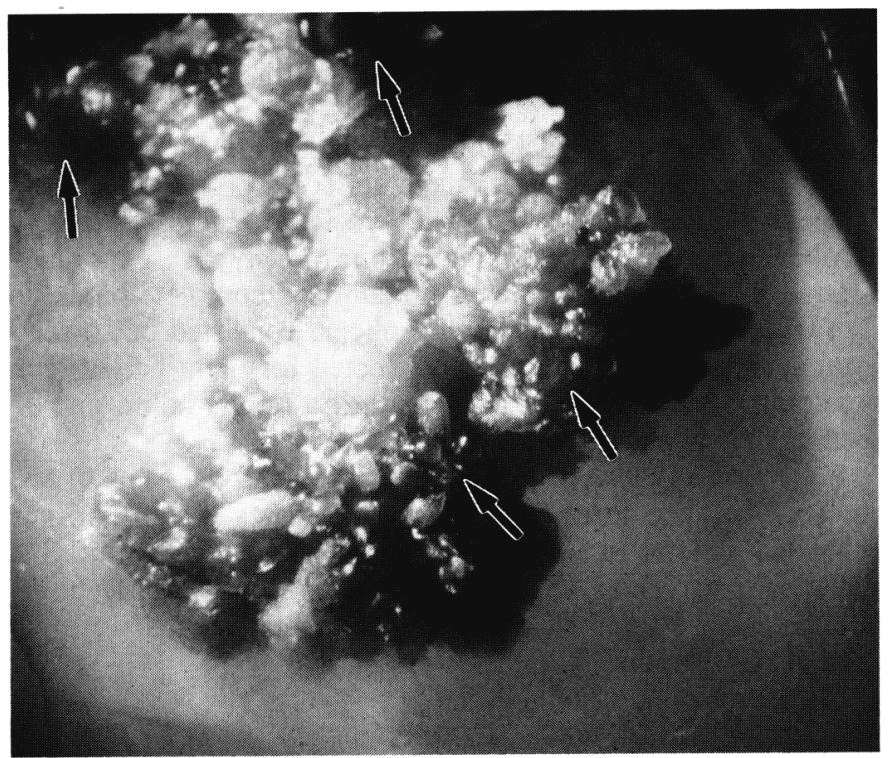

Fig. 1. Development of shoot primordia and buds (arrows) 3 weeks after transfer of bean pedicel-derived callus to media containing 1.0 $\mathrm{mg} \mathrm{BA} /$ liter.

Table 1. Effects of the type of nutrient medium ( $\mathrm{B}_{5}$ and $\mathrm{MS}$ ), and addition of benzyladenine (BA) and thidiazuron (TDZ) on the number of shoot primordia developed from first- and fifth-passage calli of two common bean lines (GN 'Tara' and Xan-159) after a culture period of 4 weeks.

\begin{tabular}{|c|c|c|c|c|c|c|c|c|}
\hline \multirow{4}{*}{$\begin{array}{l}\text { Supplements } \\
\text { in the media } \\
\left(\mathrm{mg} \cdot \mathrm{liter}^{-1}\right)\end{array}$} & \multicolumn{8}{|c|}{ Shoot primordia (no.) } \\
\hline & \multicolumn{4}{|c|}{ Passage 1} & \multicolumn{4}{|c|}{ Passage 5} \\
\hline & \multicolumn{2}{|c|}{ Tara } & \multicolumn{2}{|c|}{ Xan-159 } & \multicolumn{2}{|c|}{ Tara } & \multicolumn{2}{|c|}{ Xan-159 } \\
\hline & $\mathrm{B}_{5}$ & MS & $\mathrm{B}_{5}$ & MS & $\mathrm{B}_{5}$ & MS & $\mathrm{B}_{5}$ & MS \\
\hline $\begin{array}{l}0.0 \\
0.05 \mathrm{TDZ} \\
1.0 \mathrm{BA}\end{array}$ & $\begin{array}{c}5.1^{y} \\
9.2^{2} \\
14.8\end{array}$ & $\begin{array}{r}3.7 \\
8.1 \\
10.7\end{array}$ & $\begin{array}{r}6.0 \\
15.8 \\
41.4\end{array}$ & $\begin{array}{r}4.9 \\
13.4 \\
30.3\end{array}$ & $\begin{array}{r}2.0 \\
6.9 \\
14.9\end{array}$ & $\begin{array}{l}1.7 \\
5.2 \\
7.5\end{array}$ & $\begin{array}{r}6.0 \\
16.6 \\
40.6\end{array}$ & $\begin{array}{r}3.2 \\
10.2 \\
25.9\end{array}$ \\
\hline $\begin{array}{l}\mathrm{LSD}_{0.05} \\
\quad \text { Column } \\
\text { Row }\end{array}$ & & .12 & & $\begin{array}{l}3.3 \\
3.5\end{array}$ & & $\begin{array}{l}.5 \\
.6\end{array}$ & & $\begin{array}{l}3.7 \\
3.5\end{array}$ \\
\hline
\end{tabular}

${ }^{2}$ Cultures initiated from 40 to $50 \mathrm{mg}$ callus tissues.

'Means of four replicates over two planting dates (March and September). in Xan-159 from the fifth passage) or from the basal media (lacking BA and TDZ).

Differentiated tissues from media with $1 \mathrm{mg}$ BA/liter developed excisable shoots 5 to 6 weeks after transfer to the same nutrient media containing one-tenth the concentration of BA in the shoot induction medium, i.e., 0.1 mgliter $^{-1}$. Although shoot primordia were initiated from the callus tissues on media lacking BA and TDZ, and on media with $0.05 \mathrm{mg}$ TDZ/liter, they did not develop into excisable shoots when they were transferred to medium lacking TDZ or containing $0.005 \mathrm{mg}$ TDZ/liter. Two to five shoots per 40 to $50 \mathrm{mg}$ callus were harvested from media containing $0.1 \mathrm{mg}$ BA/liter. These shoots formed roots and elongated on media lacking BA. Regenerated plants $\left(\mathrm{R}_{0}\right)$ grew in the greenhouse and produced pods with fertile seeds (Fig. 2).

Histological study. Areas of active cell division were observed in callus tissues on the induction medium and remained active during subsequent propagation and maintenance. These active cell division areas were darker green than other adjacent callus tissues and were randomly distributed throughout the nodular callus. Initiation of new active cell division centers during serial subcultures (Fig. 3A) also was observed in callus tissues that did not have such centers developed in a previous passage. Differentiated meristem-like structures formed 2 weeks after placement of the callus on the regeneration medium (Fig. 3B), and shoot organogenesis was observed 2 weeks later (Fig. 3C).

Variant plant evaluation. No apparent variability was observed among and within progenies $\left(R_{1}\right)$ of 28 tissue culturederived GN 'Tara' plants. Out of 44 regenerants from Xan-159, two variants in plant height were found within two $R_{1}$ progenies. The evaluation of the $R_{2}$ progenies along with $S_{2}$ plants indicated significant differences $(P<0.01)$ in plant height for one of the selected variants. The mean values for plant height (centimeters) were $66 \mathrm{~cm}$ for the $\mathrm{R}_{2}$ of the selected variant and 46 $\mathrm{cm}$ for $\mathrm{S}_{2}$ of original explant source. The variant was determinate in growth habit like the original Xan-159 but had more nodes and longer internodes $(P<0.05)$. The mean number of the nodes and internode length were 4.6 and 15.1 (centimeters) for the variant and 3.9 and 13.1 (centimeters) for the original

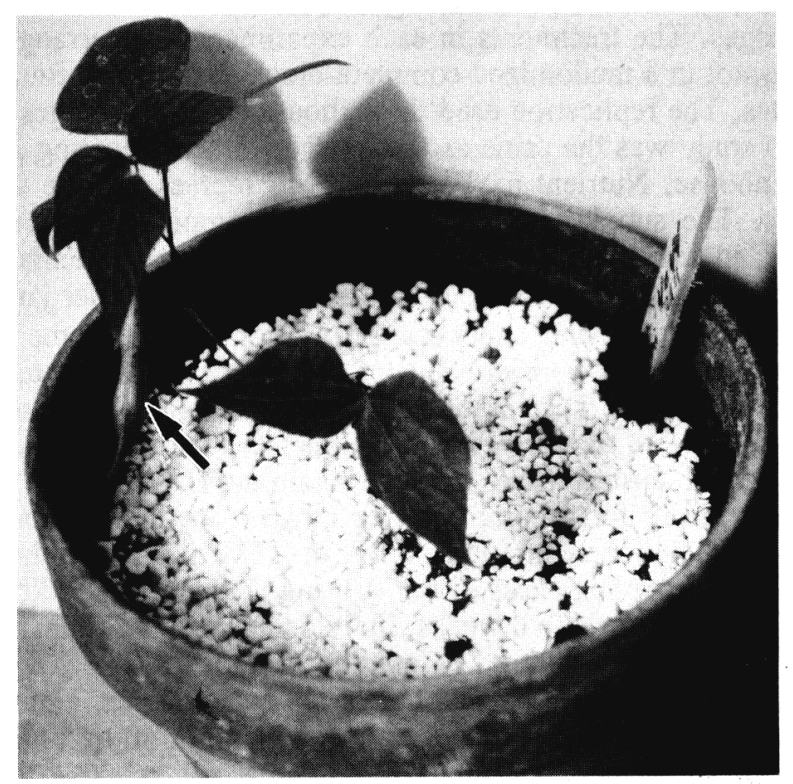

Fig. 2. Regenerated bean plants $\left(\mathbf{R}_{0}\right)$ form pedicel-derived callus producing seed-bearing pods (arrows). 


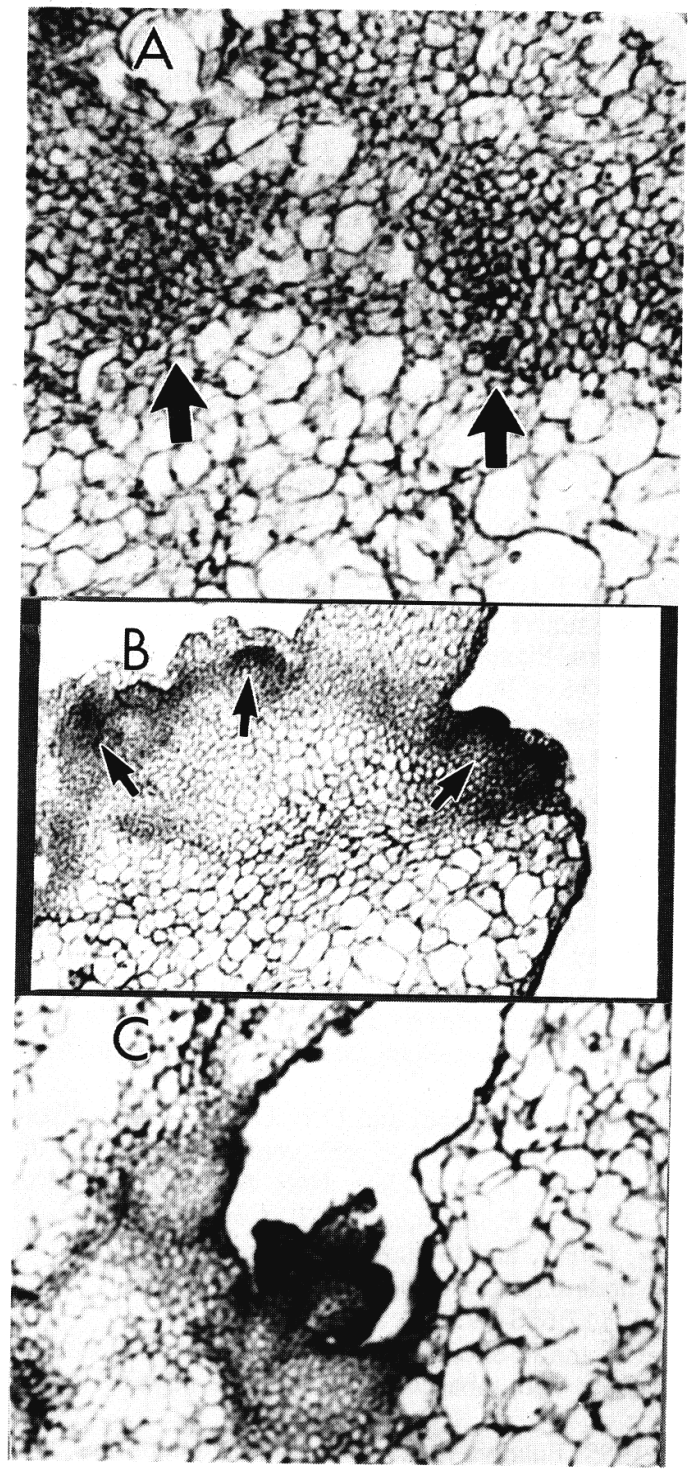

Fig. 3. Microtome sections through the morphogenic callus tissues derived from pedicel explants in common bean showing the cellular development for shoot morphogenesis: (A) The initiation of numerous areas of active cell division (arrows) in callus cultures on medium with $0.25 \mathrm{mg}$ IAA/liter and $0.5 \mathrm{mg}$ TDZ/liter. (B) The development of adventitious meristems (arrows) 2 weeks after placement of callus pieces from the fifth passage on regeneration medium containing $1 \mathrm{mg} \mathrm{BA} /$ liter. (C) Morphogenesis of shoot apices and differentiated leaves from the same cultures as in (B) after 4 weeks on regeneration medium.

Xan-159. This variant was also 7.5 days earlier $(P<0.05)$ in maturity than the original Xan-159. The mean number of days to maturity were 58 for the variant and 66 for the original Xan154. This variant line was produced from $\mathrm{R} 0$ plants regenerated from the fifth passage of callus derived from explants excised from plants of the March planting date.

\section{Discussion}

This is the first report of tissue culture methods in common bean for producing callus that can differentiate and regenerate plants. The induction of the morphogenic callus observed here was a specific property of the explant and the genotype, since that callus was induced only from pedicel explants in two common bean lines. The importance of the genotypic response in tissue culture has been recognized in grain legumes (Barwale et al., 1986; Franklin et al., 1991; Parrott et al., 1989). Both GN 'Tara' (Coyne and Schuster, 1968) and Xan-159 (McElroy, 1985) were developed from interspecific crosses with tepary bean ( $P$. acutifolius A. Gray). Tepary bean has been regenerated from callus cultures (Kumar et al., 1988). We speculate that the regeneration response of GN 'Tara' and Xan-159 may be due to a genetic component derived from tepary beans. Proliferative and viable callus was induced in the two bean lines on B5 and MS media supplemented with any of the concentrations of TDZ or IAA + TDZ tested, but only at $2 \%$ sucrose. Pedicel explants cultured on the same media lacking the callus induction factors (TDZ or IAA/TDZ) did not develop shoots from the regions that formed the morphogenic callus on the induction medium. The regenerated plants, therefore, were not derived from existing organized meristems or via proliferation of axillary buds already present in the explant. Although the development of active cell division areas were observed on the callus induction medium, new active cell centers were also initiated in subcultures from callus tissues lacking these active cell areas. This result may indicate that TDZ and IAA/TDZ have a role in the callus induction and maintenance media to initiate and induce competent tissues from pedicel-derived callus of the two bean lines. Adventitious shoot meristem formation was confirmed by the histological analysis of the callus cultures on shoot induction medium. Plant regeneration using callus derived from floral explants has not been reported previously in grain legumes; however, this type of explant has been used extensively in monocots (Brettell et al., 1980; Cai and Butler, 1990; Ozias-Akins and Vasil, 1982).

Most grain legumes regenerated in callus culture lost regenerating capability within 3 to 4 months (Kysely et al., 1987; Ranch et al., 1985). Callus cultures of common bean in our study exhibited similar behavior when maintained on IAA/TDZ media. However, when ascorbic acid was added to the maintenance media, callus was maintained for two more passages. Callus was morphogenic when tested after the fifth passage, but it did not proliferate after the sixth passage in culture. Ascorbic acid could cause the elimination of inhibitory substances; it enhanced shoot organogenesis in long-term callus cultures of tobacco ( Nicotiana tabacum L.), and reversed the inhibition of gibberellic acid on shoot formation (Joy-Iv et al., 1988).

The absence of shoot development from callus placed on regeneration media containing low concentration of TDZ may be due to carry-over effects of the relatively high concentration of TDZ used during callus induction (Mohamed et al., 1992b). BA in the regeneration media was necessary for normal shoot development from the callus. Angelini and Allavena (1989) found an increase in the regeneration frequency of $P$. coccineus on medium containing BA and $N$-(3-methyl-2-butenyl)- $1 H$-purin6 -amine (2iP), suggesting beneficial interaction between the different cytokinins. The salts and vitamins recipe of B5 nutrient medium used for cell suspension cultures of soybean (Gamborg et al., 1968) enhanced the differentiation of shoot primordia in our study in the presence of the appropriate shoot induction factor (1 mg BA/liter). Soybean leaf cultures did not regenerate shoots on MS medium and the incidence of regeneration on $\mathrm{SH}$ medium was only one-third compared to cultures grown on B5 medium (Wright et al., 1987).

One variant plant for increased height selected from R1 progeny of phenotypically similar regenerants $\left(R_{0}\right)$ in Xan-159 trans- 
mitted this trait to the $\mathrm{R}_{2}$ progeny without apparent segregation. Similar normal $\mathrm{R}_{1}$ plants in maize segregated for variants (Zehr et al., 1987), indicating chimeric regenerants $\left(\mathrm{R}_{0}\right)$. A plant regenerated via organogenesis may be genetically heterogeneous, since the organogenic pathway of regeneration may be of multicellular origin (Marcotrigiano, 1990). Putative homozygous variants have been recovered in tomato (Lycopersicon esculenturn Mill.) (Evans and Sharp, 1983), wheat Triticum aestivum L. (Larkin et al., 1984), and rice Oryza sativa L. (Oono, 1985) plants-derived from tissue culture, but evidence is lacking about the events controlling their origin. We used Xan-159 in regeneration studies via direct shoot formation (Mohamed et al. 1991, 1992a, 1992b), and no variability was observed among tissue culture-derived plants and their progeny or among plants from seed stock of this bean line. Plant regeneration from primary callus (that collected directly from the explant following the induction) and early passages of callus might be useful for genetic transformation in beans.

\section{Literature Cited}

Angelini, R.R. and A. Allavena. 1989. Plant regeneration from immature cotyledon explant cultures of bean ( $P$. coccineus L.). Plant Cell Tissue Organ Cult. 19:167-174.

Angelini, R.R., A. Genga, and A. Allavena. 1990. Tissue cultures of bean (P. coccineus L.) and their applications to breeding. Proc. 1st. Intl. ISHS symp.: In vitro culture and horticulture breeding, Cesena, Italy, p 99-104.

Bajaj, Y.P.S. 1990. Biotechnology in agriculture and forestry II: Somaclonal variation in crop improvement. Springer-Verlag, Berlin Heidelberg, Germany.

Barwale, U.B., H.R. Kerns, and J.M. Widholm. 1986. Plant regeneration from callus cultures of several soybean genotypes via embryogenesis and organogenesis. Planta 167:473-481.

Brettell, R.I.S., W. Wernicke, and E. Thomas. 1980. Embryogenesis from cultured immature inflorescences of Sorghum bicolor. Protoplasma 104:141-148.

Cai, T. and L. Butler. 1990. Plant regeneration from embryonic callus initiated from immature inflorescences of several high-tannin sorghums. Plant Cell Tissue Organ Cult. 20:101-110.

Coyne, D.P. and M.L. Schuster. 1968. 'TARA' a new Great Northern dry bean variety tolerant to common blight bacterial disease. Nebraska Agr. Expt. Stat. Bul. 506:1-10.

Evans, D.A. and J.E. Bravo. 1986. Phenotypic and genotypic stability of tissue culture plants, p. 73-94. In: R.H. Zimmerman, R.J. Griesbath, F.A. Hammerschlag, and R.H. Lawson (eds.). Tissue culture as a plant production system for horticultural crops. Martinus Nijhoff, The Hague, Netherlands.

Evans, D.A. and W.R. Sharp. 1983. Single gene mutations in tomato plants regenerated from tissue culture. Science 221:949-951.

Franklin; C.I., T.N. Trieu, R.A. Gonzales, and R.A. Dixon. 1991 Plant regeneration from seedling explants of green bean (Phaseolus vulgaris L.) via organogenesis. Plant Cell Tissue Organ Cult. 24:199206.

Gamborg, O.L., R.A. Miller, and K. Ojima. 1968. Nutrient requirements of suspension cultures of soybean root cells. Expt. Cell Res. 50:151-158.

Ghazi, T.D., H.V. Cheema, and M.W. Nabors. 1986. Somatic embryogenesis and plant regeneration from embryonic callus of soybean, Glycine max L. Plant Cell Rpt. 5:452-456.

Gomez, K.A. and A.A. Gomez. 1984. Statistical procedures for agricultural research. 2nd ed. Wiley, New York.

Joy-Iv, R.W., K.R. Patel, and T.A. Thorpe. 1988. Ascorbic acid enhancement of organogenesis in tobacco callus. Plant Cell Tissue Organ Cult. 13:219-228.

Kartha, K.K., K. Pahl, N.L. Leung, and L.A. Mroginski. 1981. Plant regeneration from meristems of grain legumes: Soybean, cowpea, peanut, chickpea, and bean. Can. J. Bot. 59:1671-1679.

Kumar, A.S., O.L. Gamborg, and M.W. Nabors. 1988. Regeneration from long-term cell suspension cultures of tepary bean (Phaseolus acutifolius). Plant Cell Rpt. 7:322-325.

Kysely W., J.R. Myers, P.A. Lazzeri, G.B. Collins, and H.J. Jacobsen. 1987. Plant regeneration via somatic embryogenesis in pea. Plant Cell Rpt. 6:305-308.

Larkin, P.J. and W.R. Scowcroft. 1981. Somaclonal variation-a novel source of variability from cell cultures for plant improvement. Theor. Applied Genet. 60:197-214.

Larkin, P.J., S.A. Ryan, R.I.S. Brettell, and W.R. Scowcroft. 1984. Heritable somaclonal variation in wheat. Theor. Applied Genet. 67:443-455.

Malik, K.A. and P.K. Saxena. 1991. Regeneration in Phaseolus vulgaris L.: Promotive role of $\mathrm{N}^{6}$-benzylaminopurine in cultures from juvenile leaves. Planta 184:148-150.

Marcotrigiano, M. 1990. Genetic mosaics and chimeras: Implications in biotechnology, p. 85-111. In: Y.P.S. Bajaj (ed.). Biotechnology in agriculture and forestry II: Somaclonal variation in crop improvement. Springer-Verlag, Berlin-Heidelberg, Germany.

McClean, P. and K.F. Grafton. 1989. Regeneration of dry bean (Phaseolus vulgaris L.) via organogenesis. Plant Sci. 60:117-122.

McElroy, J.P. 1985. Breeding dry beans (Phaseolus vulgaris L.) for common bacterial blight resistance derived from Phaseolus acutifolius A. Gray. PhD Diss., Cornell Univ., Ithaca, N.Y.

Mohamed, M.F., P.E. Read, and D.P. Coyne. 1991. In vitro response of bean (Phaseohs vulgaris L.) cotyledonary explants to benzyladenine in the medium. Plant Growth Regulat. Soc. Amer. Quart. 19:19-26.

Mohamed, M.F., P.E. Read, and D.P. Coyne. 1992a. Plant regeneration from in vitro culture of embryonic axis explants in common and tepary beans. J. Amer. Soc. Hort. Sci. 117:332-336.

Mohamed, M.F., P.E. Read, and D.P. Coyne. 1992b. Dark preconditioning, CPPU, and thidiazuron promote shoot organogenesis on seedling node explants of common and faba beans. J. Amer. Soc. Hort. Sci. 117:668-672.

Murashige, T. and F. Skoog. 1962. A revised medium for rapid growth and bioassays with tobacco tissue cultures. Physiol. Plant. 15:473497.

Oono, K. 1985. Putative homozygous mutations in regenerated plants of rice. Mol. Gen. Genet. 198:377-384.

Ozias-Akins, P. and I.K. Vasil. 1982. Plant regeneration from cultured immature embryos and inflorescences of Triticum aestivutn L. (wheat): Evidence for somatic embryogenesis. Protoplasma 110:95-105.

Parrott, W.A., E.G. Williams, D.F. Hildebrand, and G.B. Collins. 1989. Effect of genotype on somatic embryogenesis from immature cotyledons of soybean. Plant Cell Tissue Organ Cult. 16:15-21.

Ranch, J.P., L. Oglesby, and A.C. Zielinski. 1985. Plant regeneration from embryo-derived tissue cultures of soybean. In Vitro Cellular Dev. Biol. 21:653-658.

Saam, M.M., G.L. Hosfield, and J.W. Saunders. 1987. In vitro propagation of dry bean from seedling shoot tips. J. Amer. Soc. Hort. Sci. 112:852-855.

SAS Institute. 1982. SAS user's guide: Statistics. 1982 (ed.). SAS Institute, Gary, N.C.

Wright, M.S., D.V. Ward, M.A. Hinchee, M.G. Cames, and R.J. Kaufman. 1987. Regeneration of soybean (Glycine max L. Merr.) from cultured primary leaf tissue. Plant Cell Rpt. 6:83-89.

Zehr, B.E., M.E. Williams, D.R. Duncan, and J.M. Widholm. 1987. Somaclonal variation in the progeny of plants regenerated from callus cultures of seven inbred lines of maize. Can. J. Bot. 65:491499. 